\title{
Paediatric Asthma associated with passive smoking and garbage burning: A case report from Kedah, Malaysia
}

Afrose $\mathrm{T}^{1 *}$, Yeou $\mathrm{SC}^{2}$, Xi LZ ${ }^{3}$, Fernandez $\mathrm{K}^{4}$, Habib $\mathrm{N}^{5}$, Das $\mathrm{S}^{6}$

*Corresponding author:

Dr. Tahmina Afrose, MBBS, MPH, Lecturer, Department of Community Medicine, Faculty of Medicine, AIMST University, Semeling 08100, Bedong, Kedah, Malaysia.

Email: drtakeya@gmail.com ORCID

Information about the article:

Received: March 25, 2019

Accepted: Sep. 1, 2019

Published online: Oct 27, 2019

\section{Cite this article:}

Afrose T, Yeou SC, Xi LZ, Fernandez K, Habib N, Das S. Paediatric Asthma associated with passive smoking and garbage burning: A case report from Kedah, Malaysia. Journal of Biomedical Sciences. 2019;6(1):1-5

\section{Publisher}

Nepal Health Research Society, Bahundhara -6, Gokarnesowor Municipality, Kathmandu, Nepal eISSN 2382-5545, ISSN 2676-1343 (Print)

(C) The Author(s). 2019

Content licensing: CC BY 4.0

\begin{abstract}
Background

Combatting with childhood asthma is a global challenge. Exposure to allergens, air pollutants, tobacco smoke, cold air, viral infection, and family history, are the few major causative factors for asthma. An eleven years old boy from Kedah, Malaysia, had the first asthmatic attack at the age of eight. Possible causes behind the development of his asthmatic attack include passive smoking, environment pollutant created by open residential burning of rubbish practiced by his family members, repeated exposure to allergens such as pollen, house dust mite, animal dander, and eczema. The patient has been treated with inhaled

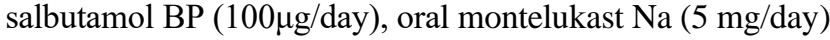
and mometasone furoate $(55 \mathrm{mcg}$. once daily). In conclusion, episodes of asthmatic attacks were mainly correlated with passive smoking \& burning garbages. Comprehensive approaches such as health education, avoidance of the allergen, cleaning, and maintaining these practices can prevent the development of this morbid illness.
\end{abstract}

Keywords

Allergen, asthma, burning bush, pollens, smoking 


\section{Introduction}

Asthma is a chronic disorder, where bronchial airways are narrow and swell, produces increased mucous. It is characterized by entirely or partially reversible airway obstruction and inflammation, which causes swelling of the airways. A variety of stimuli, such as allergens, nonspecific triggers, infections are the primary cause of asthma. Globally 300 million asthma cases are reported [1]. Asthma is the most common chronic disease among children. Childhood asthma is associated with allergy and other atopic diseases. Allergic sensitization and childhood asthma are closely associated with allergic March paradigm [2]. This can be first observed with allergic reactions with cow's milk allergy at an early age, but $95 \%$ of cases, symptoms disappear. Unfortunately, in the later years, symptoms reappear involving other organ systems. Allergic asthma, allergic rhinitis, and allergic dermatitis are the standard form of them. While approximately $60-75 \%$ of school children with asthma have been sensitized to one or more allergens, asthma may also be present without allergic sensitization. According to the Academy of Medicine of Malaysia, environmental allergens include house dust mites (D. pteronyssinus and D. farinae), cat and other dander, cockroach, fungi and pollen. Food allergy contributes only $1-2 \%$ of the population. Non- $\operatorname{IgE}$ related food and drug sensitivity may play a significant role e.g. cold drinks, food additives, and certain drugs (aspirin, NSAIDS, beta blockers, and radiological dyes) [3]. Smoking and air pollutants have significant adverse effects on airway hyperresponsiveness in Malaysia [4]. The most common symptoms include recurrent wheezing, coughing, tightness of chest, and dyspnea [5]. Asthma is diagnosed by its clinical manifestations, physical examination of the patient, and spirometry. Laboratory findings in allergic asthmatic patients often show an increased number of eosinophils, exhaled nitric oxide, and positive immunoglobulin-E (Ig-E). [6]. The preferred first-line medication for bronchial asthma is inhaled corticosteroids. In chronic or persisting case longacting beta agonist or a leukotriene agonist is preferred as a second line medicine together with a higher dose of the first line drug [7].

\section{Case report}

An eleven years old boy of Bedong, Kedah was diagnosed, with chief complains of a recurrent episode of breathlessness. Authors visited the village Jalan Kampung Baru, 08000, Bedong, Kedah, Malaysia for the purpose of community field survey. The symptoms worsened at night, and in the early morning. His mother told that his primary difficulty was a difficulty in breathing on exertion and wheezing. At eight years, his breathlessness lasted $\sim 10$ minutes. During first asthma exacerbations, he was admitted into the public hospital; based on the clinical finding and investigation report he was diagnosed with childhood asthma and since then on medication.
On further questioning, it was revealed that they dispose of garbage by open burning method, and the boy had been exposed to it since childhood. His father is a heavy smoker (20 cigarettes/day), which made him a passive smoker. Some other factors lead to a recurrent history of asthmatic attacks were exposed to allergens, such as house dust mite, pollens of flower plants, and animal such as cat. He had no family history of bronchial asthma or any types of allergy.

On general examination the boy's body mass index (BMI) was normal $\left(20.27 \mathrm{~kg} / \mathrm{m}^{2}\right)$; radial pulse rate was $82 \mathrm{bpm}$ with normal volume, rhythm and character; breathing pattern and rate were normal; palms were warm, pink and dry; had signs of allergy - dry red scaly skin over the right elbow and both ankles. He had no signs of respiratory distress, dehydration, palmar erythema, splinter hemorrhage, clubbing, central cyanosis, jaundice, anemia, or raised Jugular Venous Pressure (JVP).

Despite this, he has been suffering from eczema on his right elbow and both ankles for two years. His medical history was unusual for some session of gastroenteritis. His mother stated that he has a recurrent episode of cough with shortness of breathing two to three times per year, which subsides immediately after using an inhaler (salbutamol $100 \mu \mathrm{g})$.

The respiratory system was also found normal. On inspection, there was no sign of the use of any accessory muscles, no hyperinflation, and no Harrison's sulcus. On palpation, the trachea was centrally placed with normal chest expansion. There was no enlarged lymph node over supraclavicular fossa. Percussion showed absence of dullness or hyper resonance and on auscultation breath sound felt normal and vesicular over the upper lobes. We had followed the evaluation of asthma control of paediatric protocols for Malaysian hospitals [6]. Informed consent was obtained from the patient's guardian for history taking and systemic examination.

\begin{tabular}{|c|c|c|c|}
\hline Characteristics & $\begin{array}{l}\text { Controlled } \\
\text { All of the } \\
\text { following: }\end{array}$ & $\begin{array}{l}\text { Partly } \\
\text { Controlled } \\
\text { Any measure } \\
\text { present in any } \\
\text { week }\end{array}$ & Uncontrolled \\
\hline $\begin{array}{l}\text { Daytime } \\
\text { Symptoms }\end{array}$ & None & $>2$ per week & \multirow{5}{*}{$\begin{array}{l}\geq 3 \text { features of } \\
\text { partly } \\
\text { controlled } \\
\text { asthma present } \\
\text { in any week }\end{array}$} \\
\hline $\begin{array}{l}\text { Limitations of } \\
\text { activities }\end{array}$ & None & Any & \\
\hline $\begin{array}{l}\text { Nocturnal } \\
\text { symptoms or } \\
\text { awakenings }\end{array}$ & None & Any & \\
\hline Need for reliever & None & $>2$ per week & \\
\hline Lung function test & Normal & $\begin{array}{l}<80 \% \\
\text { predicted or } \\
\text { personal best }\end{array}$ & \\
\hline Exacerbations & None & $\geq 1$ per year & $\begin{array}{l}\text { One in any } \\
\text { week }\end{array}$ \\
\hline
\end{tabular}

The patient has been treated with inhaled salbutamol BP $(100 \mu \mathrm{g} /$ day $)$, oral montelukast $\mathrm{Na}(5 \mathrm{mg} /$ day $)$ and mometasone furoate ( $55 \mathrm{mcg}$ once daily). 


\section{Discussion}

This case report showed that the patient was well but suddenly developed breathlessness on exertion with wheezing at the age of 8 years and diagnosed as a case of bronchial asthma with an allergic origin. Allergic asthma is the most prevalent type of asthma, which usually starts in childhood.

\section{Garbage burning and asthma}

Our case report revealed that the possible causes behind the onset of illness were open burning of the rubbish. The research revealed that improper disposal of garbage, burning wastes in the open space is a significant risk for health. Pollutants emitted by this process are dioxins, fine particles, carbon monoxide, and volatile organic compounds.

Particle pollutants are microscopic particles impact severely on respiratory health; leading to severe consequences like asthma and bronchitis [8]. A study from Brazil confirmed air pollution from biomass burning and increased asthma hospital admissions in a sugar cane plantation. Which is supportive of our present findings [9]. Another research from Grenada, Caribbean showed a strong association of household bush burning practice and related respiratory symptoms. Authors reported the most common lower respiratory symptom associated with bush burning was dry cough, higher prevalence of sinusitis symptoms and had a slightly higher prevalence of cough. Prevalence of physician-diagnosed asthma and sinusitis were also more. Our report showed that the patient's family members used to dispose of the waste by the open burning method. This may be one of the possible causes that trigger the development of his childhood asthma [10].

\section{Smoking and asthma}

Passive smoking is a significant cause of respiratory illness and is associated with increased bronchial responsiveness in children $[11,12]$. This case study showed the patient's father was a chain smoker (20 number of cigarettes smoked per day) and often used to smoke at home. A higher level of $\mathrm{IgE}$ was associated with first degree relatives exposed to second-hand smoking was reported by Oryszczyn et al. [13]. History of our patient also shows higher level IgE during his first asthmatic attack.

\section{Dust mites, pollens, animal dander as a causative factor} of asthma

Continuous allergen exposure e.g. house dust mites, pollens, animal dander, etc. can cause allergic sensitization that can play a major role in the development of persistent asthma [14]. House dust mites are usually found in dust and household stuffs such as bedding, pillows, mattresses, etc. [15]. During history taking, we found the presence of plenty of flower plants in front of the patients house. So, pollens may be another factor behind the recurrent episodes of his asthma. Repeated exposure to pollens can trigger the exacerbation of bronchial asthma in sensitized person and most of the allergic trees belong to flowering groups was reported by Bush et al. [16]. Several studies had shown a strong correlation between cat dander and bronchial asthma in school children. All breeds of cat produce one of the major allergen named as Fel d 1 which is usually found in cat skin and hair follicles, and pet owner's clothing is one of the major sources of allergen spreading $[17,18]$. This study showed that the patient was rearing two kittens in his house. Recurrent exposure to cat allergen may be the other cause of sensitization and the asthmatic attack in this child.

\section{Conclusion}

Pediatric asthma is a real challenge for clinicians worldwide. Genetic factors, environmental, and diet are associated with this morbid illness. Symptoms and control of pediatric asthmatic patients should be closely monitored, as well as risk factors need to be assessed; the frequency of exacerbations needs to monitor closely. Bronchial asthma is non-curable and always needs to take careful control measures, failure of which may lead to worsening of features, or even to death. Public awareness needs to be created through different health promotion programs, emphasizing on the side effects of passive smoking, garbage burning. It would be an effective measure to combat asthma. Effective measures by implementing strategies to control allergen from pollen, animals could reduce the risk of bronchial asthma in children.

\section{Abbreviations}

Body Mass Index (BMI), Immunoglobulin-E (Ig-E), Jugular Venous Pressure (JVP), Second-Hand Smoker (SHS)

\section{Authors' contribution}

Conceptualization was done by TA, HN, KF, CYS and ZXL. Patient clerking was done by CYS and ZXL. Resources by TA, HN, KF, DS, CYS and ZXL.

\section{Competing interests}

The authors declare no conflicts of interest.

\section{Acknowledgments}

We are thankful to the AIMST University for providing us with opportunity to actively work on this informative and awareness program. We are also thankful to the patient and his parents for their cooperation.

[Disclosure: The community Medicine survey is carried out by MBBS Year 3 students of AIMST University at Jalan Kampung Baru, Kedah, Malaysia under their community medicine posting is a part of the community diagnosis module. This is part of the AIMST University curriculum and annually each batch carries out a survey at a different village in this region. The village is as identified by a liaison officer and it is selected after the village head agrees to the students carrying out a survey in their locality.] 


\section{Publisher's Note}

NHRS remains neutral with regard to jurisdictional claims in published maps and institutional affiliations.

The publisher shall not be legally responsible for any types of loss, actions, claims, proceedings, demand or costs or damages whatsoever or howsoever caused arising directly or indirectly in connection with or arising out of the use of this material.

\section{Author information}

${ }^{1}$ Dr. Tahmina Afrose, MBBS, MPH, Lecturer, Department of Community Medicine

${ }^{2}$ Soo Chun Yeou, MBBS Y-3 Batch-22 Student

${ }^{3}$ Loh Zhen Xi, MBBS Y-3, Batch-22 Student

${ }^{4}$ Prof. Dr. Kevin Fernandez, Professor, Unit Head, MBBS, MD (Nutrition) Community Medicine

${ }^{5}$ Dr. Nasrin Habib MBBS, M.Phil MPH, Senior Lecturer, Department of Physiology, Faculty of Medicine, Quest International University Perak (QIUP) City Campus, No.227, Plaza Teh Teng Seng (Level 2), Jalan Raja Permaisuri Bainun, 30250 Ipoh, Perak Darul Ridzuan, Malaysia

${ }^{6}$ Dr. Suprava Das, Senior Lecturer, MBBS, M.Phil (Pharmacology), Department of Pharmacology

${ }^{1-4,}{ }^{6}$ Faculty of Medicine, AIMST University, Semeling 08100, Bedong, Kedah, Malaysia.

\section{References}

1. GINA report. Global Strategy for Asthma Management and Prevention, 2017, Accessed online on 3.9.2019 from the URL https://ginasthma.org/wpcontent/uploads/2019/04/wmsGINA-2017-main-reportfinal_V2.pdf

2. Henderson AJ, Warner JO. Fetal origins of asthma. Semin Fetal Neonatal Med. 2012; 17(2):82-91. DOI: https://doi.org/10.1016/j.siny.2012.01.006

3. Guidelines for The Management of Childhood Asthma. A Consensus Statement Prepared for the Academy of Medicine of Malaysia. Accessed online on 3.9.19 from the

url http://www.acadmed.org.my/view_file.cfm?fileid=232

4. Azizi BH, Zulkifli HI, Kasim S. Indoor air pollution and asthma in hospitalized children in a tropical environment. J Asthma. 1995;32(6):413-8.

DOI: https://doi.org/10.3109/02770909409077752

5. van Aalderen WM, Meijer GG, Oosterhoff Y, Bron AO. Epidemiology and the concept of underlying mechanisms of nocturnal asthma. Respir Med. 1993;87 Suppl B:37-9.

DOI: https://doi.org/10.1016/S0954-6111(06)80352-5

6. Paediatric Pharmacy Services guideline (Pharmaceutical Services Division, ministry of Health Malaysia) 2015. Accessed online on 3.9.19 from the url https://www.pharmacy.gov.my/v2/sites/default/files/do cument-upload/paediatric-pharmacy-services-

guideline.pdf

7. National Heart, Lung, and Blood Institute. Expert panel report 3 (EPR-3): Guidelines for the diagnosis and management of asthma - Full Report 2007. Accessed online 3.9.19 at: https://www.nhlbi.nih.gov/sites/default/files/media/docs /asthgdln_1.pdf

8. USEPA. Human Health. Wastes - Non-Hazardous Waste - Municipal Solid Waste 2005 Accessed online on 3.9.19 from the url https://archive.epa.gov/epawaste/nonhaz/municipal/web /pdf/mswchar05.pdf

9. Arbex MA, Martins LC, de Oliveira RC, Pereira LA, Arbex FF, Cançado JE et al. Air pollution from biomass burning and asthma hospital admissions in a sugar cane plantation area in Brazil. J Epidemiol Community Health. 2007;61(5):395-400.

DOI: https://doi.org/10.1136/jech.2005.044743

10. Muge Akpinar-Elci, Olaniyi Olayinka. 2017. The Impact of Climate Change and Air Pollution on the Caribbean. Climate Change and Air Pollution, pages 349-360.

DOI: https://doi.org/10.1007/978-3-319-61346-8 21

11. Strachan DP, Cook DG. Health effects of passive smoking. 6. Parental smoking and childhood asthma: longitudinal and case-control studies. Thorax. 1998;53(3):204-12.

DOI: https://doi.org/10.1136/thx.53.3.204

12. Jang AS, Choi IS, Lee S, Nam HS, Kweon SS, Son MH et al. The Effect of Passive Smoking on Asthma Symptoms, Atopy, and Airway Hyperresponsiveness in Schoolchildren. J Korean Med Sci. 2004;19(2):214217.

DOI: https://doi.org/10.3346/jkms.2004.19.2.214

13. Oryszczyn MP, Annesi-Maesano I, Charpin D, Paty E, Maccario J, Kauffmann F. Relationships of active and passive smoking to total $\operatorname{IgE}$ in adults of the Epidemiological Study of the Genetics and Environment of Asthma, Bronchial Hyperresponsiveness, and Atopy (EGEA). Am J Respir Crit Care Med. 2000;161(4 Pt 1):1241-6.

DOI: https://doi.org/10.1164/ajrccm.161.4.9905027

14. Baxi SN, Phipatanakul W. The role of allergen exposure and avoidance in asthma. Adolesc Med State Art Rev. 2010;21(1):57-ix.

15. R. Sporik, S. T. Holgate, T. A. Platts-Mills, J. J. Cogswell. Exposure to house-dust mite allergen (Der $\mathrm{p}$ I) and the development of asthma in childhood. A prospective study. N Engl J Med. 1990; 323(8): 502507.

DOI: https://doi.org/10.1056/NEJM199008233230802

16. Bush RK, Prochnau JJ. Alternaria-induced asthma. J Allergy Clin Immunol. 2004 Feb;113(2):227-34.

DOI: https://doi.org/10.1016/j.jaci.2003.11.023

17. Kitch BT, Chew G, Burge HA, Muilenberg ML, Weiss 
ST, Platts-Mills TA et al. Socioeconomic predictors of high allergen levels in homes in the greater Boston area. Environ Health Perspect. 2000;108(4):301-7.

DOI: https://doi.org/10.1289/ehp.00108301

18. Sheehan WJ, Rangsithienchai PA, Muilenberg ML, et al. Mouse allergens in urban elementary schools and homes of children with asthma. Ann Allergy Asthma Immunol. 2009;102(2):125-130.

DOI: https://doi.org/10.1016/S1081-1206(10)60242-6 